\title{
Praktik Jual Beli Online Shop Pada PT. Shoppe Indonesia dalam Prespektif Hukum Perlindungan Konsumen di Indonesia
}

\author{
Meirza Aulia Chairani ${ }^{1}$, Moch. Juli Pudjiono ${ }^{2}$, Mudji Rahardjo ${ }^{3}$ \\ ${ }^{I}$ Fakultas Hukum, Universitas Merdeka Madiun, Jl. Serayu No.79, Madiun, 63133 \\ E-mail: meirza.aulia@unmer-madiun.ac.id \\ ${ }^{2}$ Fakultas Hukum, Universitas Merdeka Madiun, Jl. Serayu No.79, Madiun, 63133 \\ E-mail: julipudjiono@unmer-madiun.ac.id \\ ${ }^{3}$ Fakultas Hukum, Universitas Merdeka Madiun, Jl. Serayu No.79, Madiun, 63133 \\ E-mail: mudjirahardjo@unmer-madiun.ac.id
}

\begin{abstract}
The current buying and selling practice in Indonesia is very high, by using a mobile phone, one click the goods will be sent home easily. The famous online buying and selling application or online advertising, one of which is the online shop buying and selling application. Various kinds of products provided by consumers can choose what items to buy. However, sometimes the order that we buy doesn't match what we ordered. This results in losses for consumers. Lack of consumer protection in online buying and selling in Indonesia due to a lack of regulations that protect consumers, business actors, online application parties, carriers, and related parties. Therefore, this research uses an empirical juridical method, with a statutory approach and a conceptual approach.
\end{abstract}

Keywords - : consumer protection; e-commerce; buy and sell.

\section{PENDAHULUAN}

Di era serba digital saat ini semuanya serba lebih mudah dalam menjalani kehidupan. Jual beli, pinjam meminjam, transaksitransaksi lainnya yang hanya menggunakan ponsel semuanya dapat dilakukan. Transaksi jual beli beberapa waktu ini sedang banyak di gandrungi oleh beberapa orang karena kemudahannya. Beberapa aplikasi yang sering digunakan seperti Shoppe, Bukalapak, Tokopedia, dan lain sebagainya. Masyarakat dimudahkan mulai dari melakukan transaksi jual beli dalam hal memilih barang, pembayaran, dan pengiriman. Pilihan barang yang disediakan penjual berbagai macam dan berbagai harga tergantung ketelitian pembeli dalam memilih barang. Banyaknya pilihan barang kadang kala ada penjual yang tidak jujur terhadap barang yang dijualnya. Deskripsi barang dan foto yang dipajang di dalam tokonya terkadang berbeda dengan yang asli pada saat dikirimkan barangnya. Beberapa kasus ada foto dan deskripsi barang yang dikirim ke pembeli barang yang berbeda dari foto dan deskripsi.

Kasus yang pernah terjadi terhadap pelaku usaha yang menjual produk baju jualannya di tokonya dan kemudian dibeli konsumen. Konsumen membeli beberapa barang di toko Grosirhijab.solo di toko tersebut terdapat berbagai macam produk yang ditawarkan di toko mulai dari celana, baju, hijab dan lain sebagainya. Konsumen sudah melakukan pemilihan barang produk yang akan dibeli dan melakukan pembayaran melalui aplikasi Shoppe Indonesia dengan toko Grosirhijab.solo. Pengiriman oleh pelaku usaha kepada konsumen melalui jasa pengiriman agar barang sampai ketempat tujuan. Konsumen menerima barang yang dibeli dari pelaku usaha namun ada satu barang yang tidak sesuai dengan pesanan yaitu kemeja aleya bluse polos wolfis. Pesanan kemeja aleya blues polos wolfis yang di beli konsumen berwana maroon namun setelah barang datang warna yang diterima warna hitam. Pelaku usaha dalam hal ini tidak melakukan konfirmasi dan tidak ada keterangan apapun dari pelaku usaha tersebut.

Pertanggungjawaban penjual terhadap pembeli yang barang yang diterima berbeda yang diterima pembeli. Kadang kala pembeli hanya ingin uangnya kembali namun jika melalui aplikasi online pembeli harus melalui tahap-tahap untuk pengembalian uang, namun jika penjual tidak dapat dihubungi atau menghilang pembeli akan merasa dirugikan atas hal ini.

Pemerintah harus berperan dalam mengatur, mengawasi dan mengontrol sehingga sistem penjualan online untuk menjadi kondusif. Menciptakan hubungan antara penjual dan konsumen yang saling memberikan manfaat bagi kedua belah pihak. Perlindungan konsumen yang sudah diamanatkan dalam Garis-garis Besar Haluan Negara (GBHN) untuk mengarahkan kebijakan disektor ekonomi dan sektor perdagangan yang mengamanatkan bahwa pembangunan perdagangan ditujukan untuk meningkatkan pendapatan produsen sekligus menjamin kepentingan konsumen.

Berdasarkan latar belakang diatas penulis tertarik untuk mengemukaan rumusan masalah sebagai berikut:

1. Bagaimana prkatik jual beli online shop terhadap produk Kemeja aleya blues polos wolfis melalui aplikasi shoppe Indonesia?

2. Bagaimana perspektif hukum perlindungan konsumen terhadap penjualan produk Kemeja aleya blues polos wolfis melalui aplikasi shoppe Indonesia? 


\section{METODE PENELITIAN}

Penelitian hukum (Legal research) adalah menemukan kebenaran koherensi, yaitu adakah aturan hukum sesuai norma hukum dan adakah norma yang berupa perintah atau larangan itu sesuai dengan prinsip hukum, serta tindakan (Act) sesorang seuai dengan norma hukum (bukan sesuai aturan hukum ) atau Prinsip hukum. ${ }^{l}$ Metode penulisan untuk penelitian ini menggunakan penelitian yuridis normatif (Normative legal research) dan penelitian yuridis empiris (Empirical legal research). Pendekatan masalah yang digunakan dalam penelitian ini menggunakan pendekatan Perundang-undangan (Statute Approach) dan Pendekatan Konseptual (conceptual approach), dan Studi kasus (case study). Bahan hukum primer merupakan bahan hukum yang bersifat autoritatif, artinya mempunyai otoritas. Bahan hukum primer terdiri dari perundang-undangan, catatancatatan resmi atau risalah dalam pembuatan undang-undang dan putusan-putusan hakim. ${ }^{2}$ Adapun bahan hukum primer yang digunakan dalam penelitian ini antara lain:

1. Undang-Undang Perlindungan Kosumen Nomor 8 Tahun 1999 tentang Perlindungan Konsumen ( Tambahan Lembaran Negara Republik Indonesia Nomor 3821);

2. Undang-Undang Nomor 19 Tahun 2006 tentang Perubahan Undang-Undang Nomor 11 Tahun 2008 tentang Transaksi elektronik (Tambahan Lembaran Negara Republik Indonesia Nomor 5952)

Sedangkan bahan hukum sekunder semua publikasi tentang hukum meliputi buku-buku teks, kamus-kamus hukum, jurnaljurnal hukum, dan komentar-komentar. ${ }^{3}$ Pada penelitian ini yaitu buku-buku terkait tentang Hukum perlindungan konsumen, cybercrime, hukum bisnis.

\section{III.ANALISIS DAN PEMBAHASAN}

\section{A. Praktik Jual Beli Online Shop Terhadap Produk Kemeja Aleya Blues Polos Wolfis Melalui Aplikasi Shoppe Indonesia}

Penjualan online saat ini di Indonesia sangat pesat apalagi dengan adanya pandemi Covid-19 ini. Masyarakat lebih banyak dirumah terbatas melakukan kegiatan diluar. Hal ini mengakibatkan peningkatan penjulan online yang dianggap lebih mudah dan sederhana tanpa harus berkerumun di pasar. Oleh karena itu, semakin banyak pelaku usaha membuat toko online di beberapa aplikasi online atau e-commerce. Mudahnya belanja online sangat memudahkan orang untuk melakukan belanja dengan hanya memesan melalui handphone ke online shop tanpa perlu keluar ke swalayan, pasar atau pun supermarket.

Produk-produk yang dijual dari berupa makanan, pakaian, perlengkapan rumah, bahan-bahan pokok, dan lain sebagainya. Pelaku usaha dalam menjual produk dalam aplikasi jual beli ini perlu mencantumkan rincian produk, merk, jumlah barang, foto dan informasi-informasi yang perlu dicantumkan di penjelasan barang yang akan dijual. Namun kadang kala produk gambar yang diberikan pelaku usaha berbeda dengan aslinya merupakan salah satu jenis cacat produk (cacat informasi) yang sangat merugikan konsumen.

Ketidak sesuaian informasi yang diperoleh konsumen mengakibatkan kerugian kepada konsumen yang telah melakukan pembayaran kepada pelaku usaha. Kerugian ini dapat dituntut karena perbuatan melanggar hukum untuk menggugat pelaku usaha, meskipun konsumen tidak terikat perjanjian dengan pelaku usaha.

Kasus diatas konsumen membeli beberapa barang ditoko Grosirhijab.solo aplikasi shoppe yaitu berupa baju diamore top dengan warna hitam, pasmina nissa sabian dengan warna mocca, celana baggy pant dengan warna mocca, dan kemeja aleya blues polos wolfis dengan warna maroon. Dilakukanlah pembayaran barang-barang yang sudah di pilih tersebut dengan jumlah yang tertera dalam aplikasi. Kemudian pesanan diterima oleh pelaku usaha dan dikemaslah barang sesuai dengan pesanan konsumen. Setelah pembungkusan barang pesanan tersebut dikirim ke pihak pengiriman yang dipilih dan ditentukan oleh konsumen dan pelaku usaha. Kemudian pengiriman barang akan dikirim ke alamat konsumen.

Alur pemesanan praktek jual beli barang di aplikasi online shop Shoppe Indonesia :

1. Pembeli memilih barang dan toko yang akan dibelinya;

2. Pembeli menenntukan barang yang akan dibeli sesuai dengan ukuran, warna, dll, (sebelumnya sebaiknya konsumen membaca deskripsi tentang barang yang akan dibeli jika ada beberapa instruksi dari penjual)

3. Jika sudah memenutukan barang dan setuju atas diskripsi dari pihak penjual maka konsumen dapat melakukan cekout barang;

4. Konsumen memilih alamat dan jasa pengiriman untuk pengiriman barang;

5. Melakukan pembayaran atasa barang yang sudah di cekout;

6. Menunggu barang yang akan dikirim pelaku usaha kepada pengiriman;

Konsumen menerima barang tersebut kemudian melihat semua barang yang dibelinya lengkap. Namun ada satu barang yaitu kemeja aleya blues polos wolfis yang berbeda warna dari yang dipesan konsumen. Hal ini pelaku usaha juga tidak memberikan informasi kabar jika mengganti warna kaos kemeja kemeja aleya blues polos wolfis yang berwarna maroon menjadi hitam. Konsumen dalam hal ini sangat dirugikan dikarenakan pesanan yang tidak sesuai dengan pilihanya dan tidak ada konfirmasi penggantian barang dari pelaku usaha atau penjual.

\footnotetext{
${ }^{1}$ Peter Mahmud Marzuki, Penelitian Hukum (Edisi Revisi), PT. Adhitya Andrebina Agung, Jakarta,2015, h. 47.

${ }^{2}$ Ibid., h. 181

${ }^{3}$ Ibid., h. 182
} 
Beberapa cara agar barang yang tidak sesuai dengan barang yang dipilih konsumen dalam toko tersebut agar pelaku usaha tidak mengulang lagi dan mengakibatkan kerugian konsumen yaitu dengan beberapa cara :

a. Melalui chat aplikasi Shoppe mengkonfirmasi kepada pelaku usaha bahwa barang yang dikirm berbeda warna;

b. Melalui chat pribadi kepada pihak pelaku usaha jika ada nomor handphone yang bisa di hubungi bahwa barang yang dibeli berbeda warna;

c. Melalui aplikasi shoppe dengan mengklik ajukan pengembalian yaitu garansi shoppe jika produk yang diterima tidak sesuai dapat melakukan pengembalian barang/jasa dalam 2 hari sejak pesanan diterima, dengan menunjukan bukti-bukti memang barang yang dibeli tidak sesuai dengan diskripsi atau yang dipesan;

d. Melaporkanya jika pelaku usaha tidak merespon chat kita melalui aplikasi costumer service dari Shoppe Indonesia;

Beberapa cara komplain kepada pelaku usaha atau penjual hal tersebut untuk meminimalisir pelaku usaha yang tidak beritikad baik. Konsumen akan merasa terjamin dalam melakukan transaksi jual beli di aplikasi jual beli online ini. Hal ini juga termasuk kekurangan Undang-Undang Perlindungan Konsumen yang belum dapat melindungi konsumen dan pelaku usaha dalam transaksi online, terbatasnya pengertian pelaku usaha yang khususnya di wilayah Negara Republik Indonesia dan keterbatasan hak-hak konsumen yang diatur dalam undang-undang konsumen tersebut.

Pelaku usaha juga tidak dapat melakukan perbuatan-perbuatan yang merugikan konsumen karena dalam UU No. 8 tahun 1999 tentang Perlindungan Konsumen (selanjutnya disebut UU PK) sangat melindungi dan menjamin hak-hak konsumen. Namun tanggung jawab dalam melakukan jual beli online ini tidak bisa dibebankan kepada pelaku usaha saja, namun harus dilaksanakan kedua belah pihak. Jual beli secara online ini terdapat pihak-pihak yang terkait di dalamnya yaitu :

a. Penjual atau merchant yang menawarkan sebuah produk melalui internet sebagai pelaku usaha;

b. Pembeli yaitu setiap orang tidak dilarang oleh undang-undang, yang menerima penawaran dari penjual atau pelaku usaha dan berkeinginan melakukan transaksi jual beli produk yang ditawarkan oleh penjual;

c. Bank sebagai pihak penyalur dana dari pembeli atau konsumen kepada penjual atau pelaku usaha/merchant, karena transaksi jual beli dilakukan secara elektronik, penjual dan pembeli tidak berhadapan langsung, sebab mereka berada pada lokasi yang berbeda sehingga pembayaran dapat dilakukan melalui perantara dalam hal ini yaitu Bank; dan

d. Provider sebagai penyedia jasa layanan akses Internet. $^{4}$

Perdagangan secara online ini belum terlalu mendapat perlindungan secara nyata dikarenakan belum adanya pengaturan hukum terhadap perlindungan konsumen melalui perdagangan online. Lazimnya perdagangan dilakukan secara bertatap muka dan barang yang akan dibeli dapat dilihat dan dapat dipilih secara langsung oleh konsumen. Berbeda perdagangan melalui internet atau online ini konsumen tidak dapat melihat barang secara nyata dan menyentuhnya hanya dengan melihat gambarnya saja dan garis besar produk dijelaskan oleh pedagang saja di dalam tokonya. Hal ini mengakibatkan jika terjadi sengketa konsumen dalam transaksi jual beli online ini tidak dapat dijangkau oleh Undang-undang Perlindungan Konsumen.

\section{B. Prespektif Hukum Perlindungan Kosnumen terhadapa produk online shop terhadap produk aleya blues polos wolfis melalui aplikasi shoppe Indonesia}

Pengertian perlindungan Konsumen dalam Pasal 1 angka 2 UUPK adalah segala upaya yang menjamin adanya kepastian hukum untuk perlindungan kepada konsumen. Perdangan secara konvensional maupun secara online perlu adanya perlindungan terhadap konsumen untuk mendapatkan kepastian hukum sesuai pasal diatas.

Kasus diatas pelaku usaha yang mengirimkan barang kepada konsumen yang berbeda dari yang dipesan konsumen ini dalam Undang-Undang Perlindungan Konsumen dilarang dalam Pasal 8 ayat (1) huruf d yaitu tentang perbuatan yang dilarang pelaku usaha yaitu :

1) Pelaku usaha dilarang memproduksi dan/atau memperdagangkan barang-barang dan/atau jasa yang:

d. tidak sesuai dengan kondisi, jaminan, keistimewaa, atau kemanjuran sebagaimana dinyatakan dalam label, etiket, atau keterangan barang dan/atau jasa tersebut;

Pelaku usaha dalam jual beli online meliputi pelaku usaha yang menjalankan toko online yang mana memberikan jasa transaksi melalui media online. Toko online pelaku atau penjual harus mendiskripsikan barang yang dijual sesuai denga apa yang dijualnya, karena konsumen mempunyai hak informasi yang jelas dan benar dalam menggambarkan barang atau produk yang dujual penjual.

Informasi tersebut, konsumen dapat memilih produk yang diinginkan atau sesuai kebutuhannya serta terhindar dari kerugian akibat kesalahan dalam penggunaan produk(baik barang ataupun jasa). ${ }^{5}$ Perlindungan hukum terhadap konsumen dapat mendapatkan garansi pengembalian atau penukaran barang jika barang yang diterima tidak sesuai dengan yang dipesan sesuai dengan pasal diatas. Berdasarkan pasal diatas ketidak sesuaian produk yang diterima dan di jual yang tertera di pilihan took merupan bentuk pelanggranan bagi pelaku usaha dalam memperdagangkan daganganya. Hal ini bertentangan dengan Pasal 4 huruf h UU PK konsumen berhak mendapatkan kompensasi dan/atau ganti kerugian dan/atau penggantian barang yang diterima tidak sesuai dengan yang diperjanjikan atau tidak sebagaimana mestinya. Pasal 7 huruf g UU PK pelaku usaha berkewajiban

\footnotetext{
${ }^{4}$ Edmon Makarim,Kompilasi Hukum Telematika, Jakarta: PT. Raja Gravindo Persada, 2004, hal. 365.

${ }^{5}$ Ahmadi Miru dan Sutarman Yodo, 2011, Hukum Perlindungan Konsumen, Raja Grafindo Perkasa, Jakarta, 2011, h.41, dikutip dari Sudjana dan Elisantris Gultom, Rahasia Dagang Dalam Persfektif Perlindungan Konsumen, Keni Media, 2016, h.103.
} 
memberikan kompensasi, ganti kerugian dan/atau penggantian apabila barang dan/atau jasa yang diterima atau dimanfaatkan tidak sesuai dengan perjanjian.

Secara umum hak konsumen mempunyai 4 (empat) dasar konsumen yaitu: ${ }^{6}$

a. hak untuk mendapatkan keamanan (the right to safety);

b. hak untuk mendapatkan informasi (the right to be informed);

c. hak untuk memilih (the right to choose);

d. hak untuk didengar (the right to be heard).

Hak-hak konsumen diatas dapat diterima konsumen jika pelaku usaha tidak melakukan kewajibanya sebagai pelaku usaha. Disini konsumen yang dirugikan dapat mengajukan ganti kerugian melalui pihak aplikasi jual beli online shop seperti yang sudah dijelaskan diatas. Oleh karena itu, pelaku usaha juga mempunyai tanggung jawab sesuai dengan Pasal 19 UU PK bahwa konsumen berkewajiban memberikan ganti kerugaian atas barang yang tidak sesuai dengan apa yang dipesan oleh konsumen. Tanggung jawab ini juga dapat menghapus kemungkinan tuntutan dari pihak konsumen jika pelaku usaha dpaat mengajukan bukti bahwa dirinya tidak bersalah.

Konsumen dalam hal ini perlu dilindungi karena konsumen sudah melakukan transaksi yang sudah tertera dalam aplikasi $e$ commerce. Penggunaan aplikasi berbasis internet ini juga perlu pengamanan. E-commerce (perdagangan yang dilakukan dengan menggunakan sarana elektronik) adalah rangakain secara dinamis suatu teknologi, aplikasi dan proses bisnis yang menghubungkan perusahaan, konsumen dan komunitas melalui transaksi elektronik dan perdangan barang, jasa dan informasi yang diselenggarakan secara elektronik. ${ }^{7}$

Pada Pasal 1 angka 1 Dalam Undang-Undang No 19 Tahun 2016 tentang perubahan atas Undang-Undang No 11 tahun 2008 tentang ITE (selanjutnya disebut Undang-undang ITE) disebutkan definisi transaksi elektronik sebagai, "perbuatan hukum yang dilakukan dengan menggunakan komputer, dan/atau media elektronik lainnya."

Perbuatan hukum adalah perbuatan subjek hukum yang ditujukan untuk menimbulkan akibat hukum yang sengaja dikehendaki oleh subjek hukum, yaitu hak dan kewajiban yang melekat pada pihak-pihak yang melakukan perbuatan hukum tersebut, yang dalam hal ini adalah pihak konsumen dan pihak pelaku usaha.

Undang-Undang ITE Pasal 28 ayat (1) berbunyi :

1) Setiap Orang dengan sengaja dan tanpa hak menyebarkan berita bohong dan menyesatkan yang mengakibatkan kerugian konsumen dalam Transaksi Elektronik.

Ancaman pidana bagi pelaku Pasal 45 ayat (2) Undang-undang ITE yaitu penjara paling lama 6 tahun (enam) tahun dan/atau denda paling banyak 1 miliar.

Perlindungan e-konsumen, hukum memberikan perlindungan berupa hak kepada e-konsumen untuk melaksanakan kekuasaanya yaitu mengharuskan pelaku usaha untuk mengirimkan produk yang sudah dibayar. ${ }^{8}$ Kadang kala peroduk yang diterima konsumen berbeda dari apa yang dipesan, hal ini mengakibatkan kerugian pada konsumen. Hal ini mengakibatkan kedudukan konsumen menjadi lemah dalam segi perlindungan hukum. Konsumen berhak mendapatkan hak-haknya dikarenakan konsumen sudah melakukan pembayaran atas barang yang sudah dipesan tersebut. Dalam perdagangan $e$ commerce atau perdagangan konvensional pun pelaku usaha dan konsumen melaksanakan hak dan kewajibannya agar menjelaskan perlindungan konsumen.

Hak dan kewajiban konsumen dan pelaku usaha dilaksanakan sesuai dengan itikad baik maka dalam perdagangan ini akan berjalan lancar. Namun, pelaku usaha produk yang sudah dibayar oleh konsumen berhak dikirimkan kepada konsumen dan produk dikirim sesuai dengan apa yang telah dipesan, jika pelaku usaha tidak memenuhi kewajibanya maka konsumen berhak mendapatkan ganti kerugian yang dialaminya.

\section{IV.KESIMPULAN}

Dari uraian pembahasan yang telah dilakukan dapat ditarik suatu kesimpulan sebagai berikut :

1. Praktik jual beli online shop terhadap produk kemeja aleya blues polos melalui aplikasi shoppe Indonesia ini ada beberapa tahapan, tahap pertama pemilihan toko dan produk barang yang akan dibeli, kedua menentukan alamat dan pengiriman untuk cekout barang, ketiga pembayaran produk. Tahapan-tahan ini barang akan dikirim pelaku usaha atau penjual kepada konsumen melalui pihak pengiriman. Penerimaan barang jika sesuai dengan pesanan penjual akan mendapatkan pembayaran dari aplikasi jual beli online ini yaitu shoppe jika konsumen menekan atau klik pesanan diterima. Namun jika terdapat barang cacat, barang yang dipesan tidak sesuai dengan apa yang dipesan makan konsumen dapat mengajukan garansi ganti kerugian dari pihak shoppe.

2. Perspektif hukum perlindungan konsumen terhadap jual beli online shop produk kemeja polos aleya blues polos wolfis melalui aplikasi shoppe Indonesia, bahwa dalam Undang-Undang perlindungan konsumen, perlindungan hukum e-

\footnotetext{
${ }^{6}$ Empat hak ini mengacu kepada President Kennedy's 1962 Consumer's Bill of Right. Dalam perkembanganya memang tidak hanya empat hak itu yang diperjuangkan, dalam buku Shidarta,Hukum Perlindungan Konsumen Indonesia,Jakarta: PT.Grasindo,2000 hal. 19.

${ }^{7}$ Iman Sjahputra, Perlindungan Konsumen Dalam Transaksi Elektronik, Bandung: PT.ALUMNI,2010, hal. 2

${ }^{8}$ Padjadjaran Jurnal hukum, Enni soertjati priowirijanto, pengaturan transaksi elektronik dan pelaksanannya di Indonesia dikaitkan dengan perlindungan Ekonsumen, Vol. 1 No 2 tahun 2014.
} 
Website : http://yustisia.unmermadiun.ac.id/index.php/yustisia

konsumen masih kurang karena belum diatur secara jelas dalam UUPK dan UU ITE. Hal ini menyebabkan konsumen menjadi pihak yang dirugikan jika pelaku usaha tidak beritikad baik mengganti kerugian kepada konsumen. Ditinjau dari UUPK terkait kasus diatas bahwa pelaku usaha / penjual telah melanggar Pasal 8 ayat (1) huruf d bahwa barang yang dikirim oleh penjual tidak memenuhi kondisi sesuai dengan pesanan konsumen.

\section{DAFTAR PUSTAKA}

\section{A. Buku}

Peter Mahmud Marzuki, Penelitian Hukum (Edisi Revisi), PT. Adhitya Andrebina Agung, Jakarta,2015

Edmon Makarim, Kompilasi Hukum Telematika, Jakarta: PT. Raja Gravindo Persada, 2004

Ahmadi Miru dan Sutarman Yodo, 2011, Hukum Perlindungan Konsumen, Raja Grafindo Perkasa, Jakarta, 2011

Shidarta, Hukum Perlindungan Konsumen Indonesia,Jakarta: PT.Grasindo,2000

Sjahputra, Iman, Perlindungan Konsumen Dalam Transaksi Elektronik, Bandung: PT.ALUMNI,2010.

\section{B. Jurnal}

Padjadjaran Jurnal hukum, Enni soertjati priowirijanto, pengaturan transaksi elektronik dan pelaksanannya di Indonesia dikaitkan dengan perlindungan Ekonsumen, Vol. 1 No 2 tahun 2014

\section{Peraturan Perundang-undangan}

Undang-Undang Perlindungan Kosumen Nomor 8 Tahun 1999 ( Tambahan Lembaran Negara Republik Indonesia Nomor 3821);

Undang-Undang Nomor 19 Tahun 206 tentang Perubahan Undang-Undang Nomor 11 Tahun 2008 tentang Transaksi elektronik (Tambahan Lembaran Negara Republik Indonesia Nomor 5952) 